\title{
The long post-closure period of a kaolin mine
}

\author{
A longa etapa pós-fechamento \\ de uma mina de caulim
}

Camila K. Conegundes de Jesus

Departamento de Engenharia

de Minas e de Petróleo

Escola Politécnica da Universidade de São Paulo.

camilaconegundes@gmail.com

\section{Luis Enrique Sánchez}

Departamento de Engenharia

de Minas e de Petróleo

Escola Politécnica da Universidade de São Paulo.

Isanchez@usp.br

\section{Resumo}

Com a intenção de se derivarem recomendações, para uma boa prática de fechamento de mina, esse artigo examina o caso de uma mina de caulim, cujas atividades extrativas foram encerradas há mais de dez anos, e que, ainda, não se encontra satisfatoriamente recuperada, segundo os critérios do órgão ambiental. Foi constatado que (i) as medidas típicas de recuperação de áreas degradadas (reafeiçoamento topográfico, controle de erosão e repovoamento vegetal) somente foram realizadas a contento depois de retrabalho e a custos mais elevados que o estimado, e (ii) a qualidade da água subterrânea foi afetada durante as operações, o que levou a mina a ser inserida no cadastro estadual de áreas contaminadas. A mina, ainda que de pequeno porte, ilustra alguns tipos de problemas a serem enfrentados, para o fechamento de minas no Brasil: (1) falta de clareza quanto aos objetivos de recuperação ambiental, (2) necessidade de gerir o passivo representado por áreas contaminadas, (3) perda de memória organizacional. As principais recomendações de boa prática se referem a sanar as deficiências encontradas. Esse caso, relativamente simples - uma mina de pequeno porte localizada em uma região metropolitana com intensa dinâmica urbana -, nos ensina que a desativação e o fechamento não podem ser improvisados ou tratados como atividades simples ou triviais, na mineração. Ao contrário, requerem planejamento cuidadoso e integração com o próprio planejamento da mina.

Palavras-chave: Fechamento de mina, recuperação de áreas degradadas, áreas contaminadas.

\footnotetext{
Abstract

Aiming at deriving good practice recommendations for mine closure, this paper reviews the case of a kaolin mine whose production ceased more than ten years ago, but as yet didn't meet its completion criteria. Document review, interviews and site visits showed that: (i) rework was needed to satisfactorily implement land rehabilitation measures such as contouring, slope stabilization, erosion and sediment control and revegetation; (ii) underground water quality was affected during mine operation, causing the mine to be included in the State contaminated sites register. Despite being a small operation, the closure of this mine illustrates a number of problems faced by mining companies in planning and implementing mine closure measures: (1) lack of clear land rehabilitation objectives; (2) the need to manage liabilities related to contaminated sites; (3) loss of organizational memory. The research found that good practices, generally recommended in guidebooks, were not adopted by the company. The main lesson from this relatively simple case - a small mine situated near a dynamic and expanding urban area - are that decommissioning and closure cannot be a makeshift add-on to mine management; these are not trivial activities and require careful planning and integration with mine planning itself.

Keywords: mine closure, land rehabilitation, contaminated sites.
} 


\section{Introduction}

Experience with mine closure in Brazil is still limited and the documented success stories are largely restricted to quarries or small clay pits. In such cases, physical stabilization methods and reintroduction of vegetation (often with landscaping purposes), together with urban dynamics that continually demand new areas for development have led to results considered as satisfactory by stakeholders. On the other hand, experience with metal, coal or industrial mineral mines is still restricted, and there are only a few cases in which the closure process has been completed (Cunha et al., 2011).

This paper reviews the case of a kaolin mine whose extractive activities ended in 2000, but has not yet reached the stage of relinquishment, which marks the end of the closure process (ICMM, 2008). This case was chosen in an opportunistic way, given the knowledge that the authors had about the situation of the closed mine, and the possibility of consulting the documents in the files of the mining company and interviewing staff.

By compiling the history of the mine and describing the practices adopted by the company, we identify key issues in closure planning and implementation, and, to the extent possible, derive recommendations for good practice in mine closure.

\section{Methods}

The case study was conducted by collecting, organizing and analyzing information and evidence on closure-related practices obtained by (i) interviews with staff directly or indirectly involved with mine closure, (ii) review of documents pertaining to the mining processes, rehabilitation and environmental monitoring, (iii) field visits.

The following research steps were adopted:

- Identification, in the company files, of documents relevant to the purpose of the research; physical locating and gaining access to the documents was preceded by interviews with staff who possessed knowledge about the history of the mine and its activities.

- Document review in order to obtain information relevant to the research objectives.

- Preparation of a chronology of major events during the life of the mine and after its decommissioning.

- Site visit, to better understand the setting and to observe the results of rehabilitation practices.

- Analysis of information obtained with the support of technical literature on mine closure.

\section{History of the mine}

The kaolin mine named "Varinhas", located in Mogi das Cruzes municipality, São Paulo State, started its activities in the 1950s, by the company Cerâmica São Caetano, which produced china clay for the ceramics industry. The mine featured small-scale production until it was acquired by ECC do Brasil Mineração Ltda. in 1981, when a processing plant was built to meet demand from the paper industry. In 1997, this company was sold in a global transaction, which included the Varinhas mine.

In the post 1981 period, extraction was performed by hydraulic mining in two open pits, called São Caetano and Bianchi. The mineral pulp was pumped from the bottom of the pit to a coarse screening installation $(50.8 \mathrm{~mm})$, which separated grit and gravel, used for the maintenance of internal roads, from the ore. The undersize passed through a separator wheel, $1.52 \mathrm{~m}$ in diameter, which removed the coarse sand (particle size larger than $3 \mathrm{~mm}$ ). The finer pulp was pumped into a set of hydrocyclones $(172 \mathrm{~mm})$ to remove the fine sand fraction (underflow), initially pumped to a tailings dam and then disposed at the depleted Bianchi open pit. The cut in this step was 200\#. The overflow of the hydrocyclones was pumped into a spider assembly in parallel with hydrocyclones (76 mm), where separation occurred at $37 \mu \mathrm{m}$. The coarse kaolin fraction (underflow from the second hydrocyclones set) was transferred to a ball mill, whose product was fed back to the $172 \mathrm{~mm}$ hydrocyclones. The fraction of fine kaolin (overflow) was pumped into a battery of horizontal vibrating screens, in parallel, with a $63 \mu \mathrm{m}$ deck. The oversize was discarded as waste and the undersize was transferred to sedimentation tanks with capacities of $15000 \mathrm{~m}^{3}$, to thicken the kaolin. The next step in the process was bleaching the kaolin, which averaged $64 \%$ in brightness, attacking it with a sodium hydrosulfite solution, transforming insoluble trivalent iron into soluble bivalent iron. The bleached kaolin, now freed from most iron and averaging $85 \%$ in brightness, was pumped into two tanks and stored with $30 \%$ solids, on average, to be transferred to a press filter. Kaolin, in the form of final product, was shipped as slurry (suspended in water). After being filter pressed, the kaolin cakes, featuring about $70 \%$ in solids, were transferred to mixers to disperse and dilute the material, reaching about $55 \%$ in solids. Afterwards, the kaolin was pumped into storage tanks and then loaded into tanker trucks.

At the end of 2000, the mine was closed after 19 years of industrial scale mining with annual output averaging 250,000 tons of kaolin. However, at the time of closure, the mine still had mineral reserves of about 1,250,000 tons, whose extraction was not considered economically viable, as they were located under the ore beneficiation plants, typifying one of the forms of early closure (Sánchez, 2011), before exhaustion of mineral reserves.

\section{Initiatives directly related to the mine closure}

The first actions taken by the company that may be associated with some prospect of closure are those related to compliance with legal requirements con- cerning rehabilitation of degraded areas, in accordance with the approval of the 1988 Constitution (Article 225). A Land Rehabilitation Plan (PRAD in the Brazil- ian acronym -"Plano de Recuperação de Áreas Degradadas") - was filed in October 1989 , in compliance with the 180-day period stipulated by Federal Decree 97,632 
for all mining activity in the country. In its early days, mine rehabilitation was characterized by the lack of technical guidelines (Sánchez, 2010) and guidance from regulatory agencies. This case was typical of that period, since, many years later, the Department of Environmental Impact Assessment - DAIA ("Departamento de Avaliação de Impacto Ambiental"), part of the Sao Paulo State Environment Secretariat (Secretaria do Meio Ambiente do Estado de São Paulo - SMA), reviewing the Land Rehabilitation Plan, considered it to be unsatisfactory, prompting the company to submit a new one in 1999.

In parallel, when the SMA sector in charge of pollution control - Cetesb - identified problems of groundwater contamination, it determined that the company make further studies, still during the operational period of the mine. At that

\section{Land rehabilitation}

A technical report from the Department of Environmental Impact Assessment PT/CPRN/DAIA/220/2000 dated July 18, 2000, reviewing the second Land Rehabilitation Plan, filed in 1999, states that "the concept submitted, supplemented by the requirements defined in this Report, is suitable to stabilize the topography of the area", referring to the plan to be reviewed by other government bodies. This Department established a list of 24 requirements. The mention of "other departments" is typical of bureaucratic fragmentation of SMA at that time (Dias and Sánchez, 1999, 2001), where pollution issues were addressed by a pollution control agency (Cetesb), natural vegetation by another (DEPRN - Department of Protection of Natural Resources) and those relating to protection of water sources by a third entity (DUSM, Department of Metropolitan Land Use). These other agencies could establish other requirements for the entrepreneur.

The actions described in the rehabilitation plan and the additional requirements resulting from governmental review were implemented by the company, which hired the services of various environmental consulting firms. In 2001, the company "RAS do Brasil" prepared three "Technical Reports on the Implementation of Works from the Prad" respectively in February, April and June. These reports cover the period from December 2000 to May 2001, therefore after mine closure. The following actions are reported: slope time, Cetesb progressed in formulating a strategy for management of contaminated areas (Sánchez, 2004) and went to publish the first edition of its manual (Cetesb, 2001), as well as reference values of soil and groundwater quality (Casarini et al., 2001). Such actions of the pollution control agency came to be further supported by the State Law 13,577 of 8 July 2009.

Technical studies, field inspections and meetings between environmental agencies and the company occurred, intensifying over the closure year. The company's environmental liabilities were twofold: (1) land degradation and (2) groundwater contamination. The company also undertook other actions in its approach to closure, especially dismantling of the beneficiation plant, the demolition of most buildings and structures, and decommissioning of the tailings dam.

abatement in the São Caetano pit, fencing the area with barbed wire, planting seedlings, revegetating the slopes, soil fertilization and building runoff drains. All services were performed by a contractor.

In December 2001, DEPRN - the agency with responsibilities for the protection of native vegetation -, after a site inspection, issued a document entitled Statement of Commitment for Environmental Rehabilitation - (TCRA in the Brazilian acronym -Termo de Compromisso de Recuperação Ambiental - TCRA no. 249/01), determining that the company should make an additional planting of 4000 seedlings of native species.

In 2003, the consulting firm "Multigeo" prepared a report entitled "Slope Recontouring and Revegetation Project". It informed that the actions to implement the rehabilitation plan had been paralyzed in 2001, with no maintenance or followup. This new study aimed at planning the short-term corrective actions, but it also shows deficiencies in the second PRAD (filed in 1999, which hindered its implementation. Problems included lack of information about "location of each element of the drainage system and criteria for calculating the design flow", as well as an "incomplete topographic map". There was, therefore, a need for a double rework, i.e. the preparation of a new PRAD, of a more executive nature, and the correction of the actions previously implemented. The study by Multigeo included:

- Reviewing geomechanical estimates
However, no records related to these initiatives were found in the company's files, perhaps because they were actions taken internally by the company and not as a response to government requirements. In contrast, copies of documents submitted to State authorities and correspondence received were filed and maintained.

Only from December 2002 on, the State government, after publishing Decree 47400, started to require the submission of a Decommissioning Plan for projects subject to environmental licensing, a requirement already adopted in other jurisdictions (Sánchez, 2001). As such document was not prepared for the Varinhas mine, this section presents the results obtained in interviews and archival work enquiring about land rehabilitation initiatives and the management of the contaminated area.

for the final slopes.

- Dimensioning of the drainage system.

- Dimensioning of earthworks need for recontouring.

- Estimating costs for drainage and embankment services ( $\mathrm{R} \$ 450,000)$.

- Preparing guidance for slope revegetation of slopes (total area 159,000 $\mathrm{m}^{2}$ ) and seedling planting around the flooded pits (total area 20,200 $\mathrm{m}^{2}$ ).

- Estimating total revegetation cost $(\mathrm{R} \$$ $2.50 / \mathrm{m}^{2}$ for the slopes, and $\mathrm{R} \$ 24,240$ for seedling planting, a total of $\mathrm{R} \$$ 421,000).

Also in 2003, a DEPRN team performed a site inspection and determined a new Statement of Commitment for Environmental Rehabilitation - TCRA (no. 277/03). In August of that year, the implementation of the Multigeo plan started. A "Report on the Progress of Rehabilitation Works in the Mined Area" was prepared and in November of that year, services were completed and the consulting company issued the "Final Report of Mine Rehabilitation," reporting the actions implemented. By the time of completion, new national regulations had been issued on the protection and the restoration of riparian vegetation (National Environment Council - Conama - Resolution 302/2002), which includes pit lake margins. Therefore, rehabilitation included planting seedlings of native trees in the flooded pit margins. Figures 1 and 2 show views of both pits at the end of the operational phase, featuring earthmoving 
works for recontouring and slope stabilization and after the establishment of grass cover and tree seedling planting.

In 2004, Multigeo prepared the "First Semester Monitoring Report", describing the works of ecological restoration undertaken in 2003 and the maintenance activities carried out in April 2004. In October of that year, another contrac-

tor, "WMT Ambiental", prepared a "Report on the Maintenance of Reforestation with Native Forest Species", describing the technical and operational maintenance activities: manual mowing, weeding, topdressing, alignment and marking of holes for replanting, preparation of the soil substrate conditioner, manual tillage, ants extermination, fertilizing for replanting,
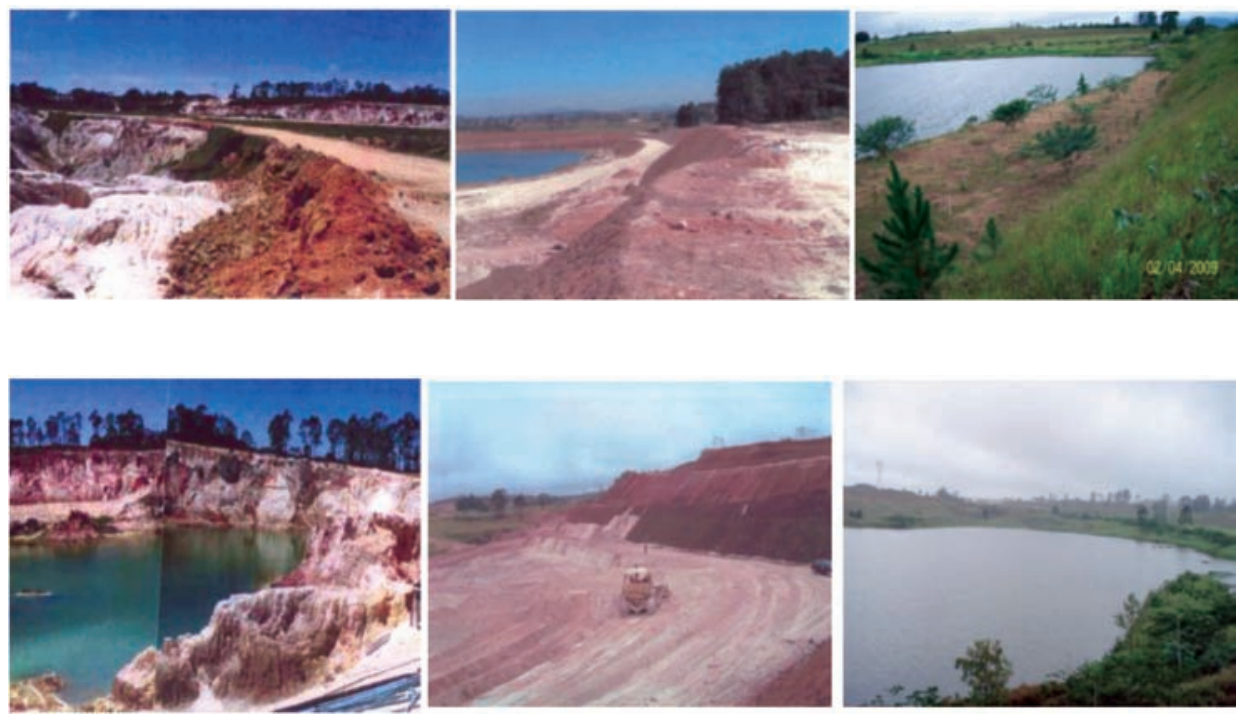

\section{Remediation of contaminated areas}

Groundwater contamination was known in the site since the early 1990s, having been the subject of several studies since then. In December 2001, after mine closure, Cetesb (the pollution control agency) request the company to submit a Remediation Plan. In December 2003, the consulting company "Consultoria Paulista de Estudos Ambientais" concluded the report "Monitoring and Evaluation of Soil Quality, Sediments, and Surface Water and Groundwater in the Surroundings of the Decommissioned Mine and Kaolin Beneficiation Plant". This report addresses the requirements of PT/CPRN/ DAIA/220/200 (mentioned at the beginning of section 4) for the monitoring of water and sediment and reached the following main conclusions:

- Surface water and groundwater were contaminated by sulfates, phosphates and zinc.

- Following decommissioning of the beneficiation plant (primary source of pollutants), the trend was for contaminants to decay with time, but as another mine was operating in the surroundings, additional contaminants could reach the groundwater.

- The tailings dam used jointly by the two companies continued to release contaminants, particularly sulfate and zinc, to groundwater and surface water downstream, reaching a small stream, thus requiring control measures. This contamination, however, was not enough to affect the downstream water quality of the Doce and Taiaçupeba creeks and Taiaçupeba reservoir, used for public supply.

In the process of ore beneficiation, chemicals had been used to reduce $\mathrm{pH}$ and as a catalyst (metallic zinc) for bleaching kaolin, with an average monthly consumption of 8 to 10 tons of zinc. According to Terrell (2007), it was not possible to quantify how much of this portion was incorporated into the final product to be marketed and how much remained embedded in tailings and wastewater.

In the late 2005, Cetesb and the company signed a Statement of Commitment of Adjustment of Conduct (TAC, in the Brazilian acronym, a legally binding out-of-Courts agreement under Brazilian environmental law). In this statement, the company, agreed to:

- Expand the groundwater monitoring wells network.

- Deploy and present geological profiles of the new monitoring wells.

- Undertake a detailed hydrogeological seedlings replanting, and growth followup. Between April 2005 and April 2009 fourteen "Monitoring Reports - TCRA (Statement of Commitment for Environmental Rehabilitation)" were prepared by different contractors: "Metaflora", "Empório Verde" and two self-employed workers. All reports, in general, describe the silvicultural treatments done on site.

Figure 1

São Caetano pit at operation (L), decommissioning in $2003(\mathrm{M})$ and under rehabilitation in 2009 (R).

Figure 2

Bianchi pit at operation (L), decommissioning in 2003 (M) and under rehabilitation in 2009 (R). characterization of the contaminated area.

- Achieve detailed investigation of soil and groundwater.

- Prepare and submit quarterly monitoring of groundwater and surface water.

- Define and delineate a possible contamination plume.

- Prepare a risk analysis.

- Submit a technical proposal to select the best action strategy to block possible sources of contamination.

- Implement systematic environmental audits to identify possible sources of contamination.

In terms of relevant issues related to mine closure, it is interesting to note the following passage (emphasis by authors): "The Statement of Commitment of Adjustment of Conduct will be in force indefinitely, (...). This Statement (...) will be considered terminated after the faithful, full and complete compliance by the (...) [company] of all obligations considered to be part of this." (emphasis added)

In compliance with the TAC and current Cetesb's policy on management of contaminated areas, a risk analysis was performed by the consultant, concluding that it would not be necessary to undertake any remedial action in addition to monitoring. 


\section{Current situation}

At the end of 2011, the area is still under responsibility, care and maintenance of the mining company, which maintains a full time person and hired a contractor for maintenance works. Monitoring of groundwater quality, which started in February 2004, continues, with reports sent quarterly to Cetesb. Monitoring is done on a network of thirty wells distributed upstream, within and downstream of the area; potentiometric maps are updated after each field monitoring.

\section{Discussion}

In the absence of a specific legal framework, as well as corporate guidelines for mine closure, decommissioning the Varinhas mine was driven by the legal requirement to prepare a rehabilitation plan and State regulations for the management of contaminated areas, under preparation at the time of closure. In terms of land rehabilitation, both planning and execution of the services were outsourced to different consultancies and contractors without adequate supervision exercised by the mining company. Consequently, both the rehabilitation plan and the implementation of the measures it recommended were subject to considerable rework. Activities related to restocking vegetation are still ongoing, currently in the phase of monitoring and maintenance.

Regarding the management of contaminated sites, the company has been following the various orders issued by the State pollution control agency and running a comprehensive program of monitoring of groundwater, still ongoing. Groundwater contamination is the main

\section{Conclusions}

The main lessons that can be learned from this case do not relate strictly to good practices that can be replicated, but possibly to avoiding recurring problems that directly influence the success of environmental remediation and mine closure.

The Varinhas mine, although a small one, illustrates some types of problems to be faced in the closure of mines in Brazil: (1) lack of clarity about the targets and several shortcomings in the implementation of rehabilitation actions, (2) a need to manage liabilities for a long time frame,
In the State Record of Contaminated Sites (Cetesb, 2010), the site also features as contaminated by "metals" in the media "soil, subsoil, surface water and groundwater" both on-site and off-site. Out of the steps provided by state regulation for the management of contaminated areas, the mine area, having gone through the phase known as confirmatory investigation (including risk analysis), is in the process of remediation, under the prescription of "environmental monitoring".

Thus, for eleven years, the company

issue to be resolved for the area to be released for further use. From the beginning of the regular quarterly monitoring (started in February 2004), declining contaminant concentration is being observed, but it remains unclear when a remediation outcome could be achieved. Hence, this case clearly shows that the needs of the mine closure transcend the measures presented in a land rehabilitation plan (Lima, 2006).

Since mining ceased in 2000 , the company remains responsible for the area and is expending funds in this process. According to the conceptual models of the life cycle of mines (ANZMEC/MCA, 2004; Australia, 2006; ICMM, 2008), Varinhas mine still is - after eleven years - in a post-closure phase without having been able to move to the relinquishment phase and without a foreseeable expectation for completion of obligations imposed by the environmental agency.

One of the most striking features in the case of the Varinhas mine is the succession of contractors and consulting has remained responsible for and has been coping with associated care and maintenance costs of the closed mine site. Although the results of groundwater monitoring indicate an apparent trend of reduction in the parameters of concern, there is no way to predict when the mine can change its category to "remediated area fit for declared land- use", as defined in state law, i.e. only certain types of new land-uses will be possible, with permanent restrictions imposed on the property title. companies, as well as staff turnover. In such conditions, combined with poor management of information from the mining company, it appears that there is no organizational memory about the different and successive steps of rehabilitation and remediation, nor ability to identify risks, a phenomenon that has been observed by Neri and Sánchez (2010) in other mining companies and is called organizational amnesia (Othman and Hashim, 2004). Besides the successive rework of rehabilitation planning and implementation mentioned in section 4 , other evidence of organizational amnesia obtained in this study were verified by one of the authors (CKCJ) when conducting interviews in the mining company, and the other author (LES), years before, when visiting the area, observed that management was unaware of the existence of the tailings dam mentioned in section 4, now decommissioned; although small, it was built by the upstream method, thus requiring care to be exerted in decommissioning.
(3) loss of organizational memory. Social and economic issues on the local scale, potentially important in planning the closure of large mines, were not identified in the case study.

The main recommendations that the analysis of this case may bring to the practice of mine closure in Brazil refer to how to remedy the deficiencies, which, essentially, means applying the recommendations of guides and manuals for mine closure, as those mentioned in section 5 , among others.

It is noteworthy, in this case, the finding that, if the opening of a new mine requires careful planning and demands relatively long periods of time, the same should be applied to the closure of a mine. This relatively simple case - a small mine located in a metropolitan region with intense urban dynamics - teaches us that decommissioning and closure cannot be improvised or treated as trivial or simple activities in mining. Instead, they require careful planning and integration with proper planning and mine operation - in this case, especially to prevent the contamination of groundwater. 
On the other hand, a clearer regulatory guidance could have served for the company to decommission and to close the mine according to a predetermined plan and with greater chances of success. Accordingly, as more mines reach the end of life, a definition - by law or regulation - of the companies' responsibilities will help to reduce the uncertainties in this question.

\section{References}

ANZMEC/MCA, Australian and New Zealand Minerals and Energy Council/ Minerals Council of Australia. Strategic Framework for Mine Closure. Canberra: ANZMEC/MCA, 2004.

AUSTRALIA, Mine Closure and Completion. Canberra: Department of Industry, Tourism and Resources, 2006.

CASARINI, D.C.P. et al. Relatório de estabelecimento de valores orientadores para solos e águas subterrâneas no Estado de São Paulo. São Paulo, 2001. 73 p.

CETESB, Companhia de Tecnologia de Saneamento Ambiental. Manual de gerenciamento de áreas contaminadas. São Paulo, Cetesb, 2001.

CETESB, Companhia de Tecnologia de Saneamento Ambiental. Cadastro de áreas contaminadas. 2010. Available http://www.cetesb.sp.gov.br/userfiles/file/areascontaminadas/ordem_munic_dez_10.pdf, last access Feb 42012.

CUNHA, M.F.M., LIMA, H.M., FLORES, J.C.C. Overview of mine closure in Minas Gerais. REM - Revista Escola de Minas, v. 64, n.2, p. 205-211, 2011.

DIAS, E.G.C.; SÁNCHEZ, L.E. A participação pública versus os procedimentos burocráticos no processo de avaliação de impactos ambientais de uma pedreira. Revista de Administração Pública, v. 33, n. 4 p 81-91, 1999.

DIAS, E.G.C.S., SÁNCHEZ, L.E. Deficiências na implementação de projetos submetidos à avaliação de impacto ambiental no Estado de São Paulo. Revista de Direito Ambiental, v. 6, n. 23, p. 163-204, 2001.

ICMM, Conselho Internacional de Mineração e Metais. Planejamento para o fechamento integrado de mina: kit de ferramentas. London: ICMM, 2008. Publicado em português pelo Ibram, Instituto Brasileiro de Mineração.

LIMA, H.M. et al. Plano de recuperação de áreas degradadas versus plano de fechamento de mina: um estudo comparativo. REM - Revista Escola de Minas, v.59, n. 4, p. 397-402, 2006.

NERI, A.C.; SÁNCHEZ, L.E. A procedure to evaluate environmental rehabilitation in limestone quarries. Journal of Environmental Management, v. 91, p. 2225 2237, 2010.

OTHMAN, R., HASHIM, N.A. Typologizing organizational amnesia. The Learning Organization, v. 11, p. 273-284, 2004.

SÁNCHEZ, L.E. Revitalização de áreas contaminadas. In: MOERI, E., COELHO, R., MARKER, A. (org.), Remediação e revitalização de áreas contaminadas: aspectos técnicos, legais e financeiros. São Paulo: Signus, 2004. p. 79-90.

SÁNCHEZ, L.E. Planejamento e gestão do processo de recuperação de áreas degradadas. In: FILIPPINI-ALBA, J.M. (org.), Recuperação de áreas mineradas: a visão dos especialistas brasileiros. (2. ed.). Brasília: Embrapa Informação Tecnológica, 2010, cap. 2, parte 2, p. 103-121, 326 p.

SÁNCHEZ, L.E. Planejamento para o fechamento prematuro de minas. REM Revista Escola de Minas, v. 64, n. 1, p. 117-124, 2011.

TERRELL, D. Avaliação da qualidade da água subterrânea em área de mineração de caulim: impactos e perspectivas de remediação, município de Mogi das Cruzes, SP. São Paulo: Instituto de Geociências, Universidade de São Paulo, 2007. 97 p. (Tese de Mestrado).

Artigo recebido em 28 de setembro de 2012. Aprovado em 04 de abril de 2013. 